\title{
Building Students' Critical Thinking Skills through Authentic Learning by Designing Eco-brick Social Campaigns
}

\author{
Mega Elvianasti ${ }^{1,}$ Meitiyani², Maesaroh3, Irdalisa4, Husnin Nahry Yarza5 \\ DOI : $10.35445 /$ alishlah.v13i3.389
}

InfoArtikel

Abstract

Keywords:

Authentic learming;

critical thinking;

eco-brick

Kata kunci:

Pembelajaranotentik;

Berpikir kritis;

Eco-brick
Critical thinking skills are included in the ten skills needed in the era of the industrial revolution 4.0. Students are trained to be able to analyze problems and find solutions from various sources. To enhance the critical thinking skills of students, activities that can be developed are needed, namely through authentic learning, one of which is designing an eco-brick social campaign to overcome plastic waste. Authentic learning activities are in the form of real-world relevance, multiple sources and perspectives, collaboration, reflection, illdefined problems, and sustained investigation. The quasi-experimental method was used in this study, with the research subjects being 62 students in one of the East Jakarta Junior High Schools in grades $7 \mathrm{~F}$ and $7 \mathrm{H}$. The data analysis technique in this study was to analyse the results of validity, normality, homogeneity, and independent t-test using SPSS 20 as a statistical tool. According to the research results, it was found that the difference in the average critical thinking ability between groups of students, experiment class with authentic learning treatment revealed $80.73 \%$ and control class showed $70.37 \%$. A large number of students have difficulty in critical thinking, namely in the aspect of explaining reasons. Meanwhile, in designing eco-brick social campaigns, the experimental class is in a pretty good category, so it can be revealed that students can build critical thinking skills in solving problems through authentic learning to design eco-brick social campaigns and it is suggested that the different contents in the form of authentic learning in creating socialcampaigns can be developed.

\section{Abstrak}

Salah satu keterampilan yang dibutuhkan di era revolusi industri 4.o adalah keterampilan berpikir kritis, dengan menggunakan berbagai sumber siswa dapat melatih diri untuk menganalisis masalah dan mencari solusinya. Untuk meningkatkan kemampuan berpikir kritis siswa diperlukan kegiatan yang dapat dikembangkan yaitu melalui pembelajaran autentik salah satunya merancang kampanye sosial eco-brick untuk mengatasi sampah plastik. Kegiatan belajar yang otentik adalah dalam bentuk relevansi dunia nyata, berbagai sumber dan perspektif, kolaborasi, refleksi, masalah yang tidak jelas, dan penyelidikan berkelanjutan. Metode yang digunakan dalam penelitian ini adalah eksperimen semu, dengan subjek penelitian sebanyak 62 siswa di salah satu SMP Negeri Jakarta Timur kelas $7 \mathrm{~F}$ dan $7 \mathrm{H}$. Teknik analisis data menggunakan SPSS 21 dengan melakukan uji validitas, normalitas, homogenitas, dan independent t-test. Berdasarkan hasil penelitian diketahui bahwa perbedaan rata-rata kemampuan berpikir kritis antar kelompok siswa, kelas eksperimen dengan perlakuan pembelajaran otentik sebesar 80,73\% dan kelas kontrol sebesar 70,37\%. Pada aspek menjelaskan alasan, sebagian besar

1,2,3,4,5Un iv ersitas Mu hammadiyah Pr of. Dr. Hamka, Jakarta Timur, In donesia

Em ail: megaelvianasti@uhamka.ac.id

Vol.13(3) December, 2021

Received: February 15, 2021; Received in revised form: Maret 18, 2021; A ccepted: October 19, 2021; A vailable online: November 22, 2021. Th is is an open access article under a Creative Com mons Attribution -NonCom mercial-ShareAlike 4.o International License 


\begin{abstract}
siswa mengalami kesulitan dalam berpikir kritis. Sedangkan dalam merancang kampanye sosial eco-brick, kelas eksperimen berada pada kategori cukup baik, sehingga dapat diketahui bahwa melalui pembelajaran autentik merancang kampanye sosial eco-brick siswa dapat membangun keterampilan berpikir kritis dalam memecahkan masalah dan disarankan agar konten yang berbeda dalam bentuk pembelajaran otentik dalam membuat kampanye sosial dapat dikembangkan.
\end{abstract}

\title{
INTRODUCTION
}

Students' critical thinking skills are not only limited to the learning experiences gained by students. According to the World Economic Research Forum (Loseby, 2019), in the future, critical thinking skills are included in the ten skills needed including complex problem solving, critical thinking, creativity, ability to manage others, coordination with others, emotional intelligence, ability to convey opinion and decision to make a decision, to focus on services, negotiation, and flexibility of cognition. On the other hand, critical thinking skills use rational and reflective thinking skills to decide what to believe or do. Critical thinking is oriented towards understanding something that is done consciously and leads to a goal. One of the important goals is to help someone make the right and best decisions (Sarimanah, 2017). It is supported by the implementation guidance of the $21^{\text {st }}$ Century by the Ministry of Education and Culture which states that critical thinking is related to the ability to assess and decide effectively through data analysis and argumentation.

The ability to critically think is the target of industrial revolution 4.0. This is because PISA and TIMSS questions are designed based on critical thinking skills in the world of education. Critical thinking is an active, continuous, and thorough consideration of a belief or knowledge form taken for granted by including supporting reasons and rational conclusions (Rachmadtullah, 2015). In addition, according to Ennis (2011), critical thinking skills can facilitate students in understanding and analyzing a problem; students can consider decisions and conclude existing problems. These problems can activate students' skills of critical thinking.

Critical thinking is very important to be equipped with students from low to high levels because, in the future, this ability is needed in overcoming various problems. The problem that will continue to be faced by the community is the excessive use of plastic, resulting in uncontrolled plastic waste. Plastic contains chemical compounds that cannot be destroyed directly by decomposing microorganisms; it takes thousands of years to decompose plastic in the soil. To overcome this, plastic recycling can be done through eco-bricks. Eco-brick is a PET bottle packaged with clean and dry used plastic and made with a predetermined density (Ecobrick.org). The results of eco-brick can be used as materials for buildings, as decorations, materials for making chairs, etc. So that students are able to enhance critical thinking skills to overcome the problem of plastic waste, activities through authentic learning are needed. Authentic learning can help increase students' motivation and enthusiasm, as well as assist students in making decisions and identifying non-conventional ways to improve learning (Maina, 2004).

King et al. (2009) state that critical thinking abilities are included in the criteria and standards for implementing genuine learning in higher education institutions. Knowing how to organize, interpret, and evaluate information is essential for students who want to pose challenging questions, undertake investigations using a variety of information sources, and tackle seemingly insurmountable difficulties. According to (Lombardi, 2007), the reference for genuine learning activities is contained in the learning implementation plan (lesson plan). It includes the following information: real-world The importance of relevance students are allowed to investigate abstract concepts and facts. The topics are relatable to students' everyday experiences. Many different approaches have been used to improve critical thinking skills (Bustami et al., 2018), including the CTL model (Noviyanti et al., 2019), guided discovery learning models (Lukitasari et al., 2019), and 
blended learning (Lukitasari et al., 2019). However, no one has used authentic learning to improve students' critical thinking skills. Collaborating on real learning projects such as designing eco-brick social campaigns can lead to the development of innovative and critical answers to the problems that have been set forth.

\section{METHODS}

This study employed Quasi-Experimental Design. The population in this study is seventhgraders from one of the state junior high schools in East Jakarta. The research sample was determined using random cluster sampling and obtained class $7 \mathrm{~F}$ as the experimental class and $7 \mathrm{H}$ as the control class. The selection of research samples was carried out based on considerations of conformity with the aims and objectives of the study, and the sample was considered representative (Fraenkel \& Wallen, 2009). Data analy sis was carried out after the construct validity test, homogeneity test, and normality test. The independent t-test was processed using SPSS 20. The research instrument was an essay about critical thinking as many as seven questions with environmental pollution material and an assessment rubric instrument for eco-bricks products. The essay question instrument was first validated by the question validator. The indicators for the skills of critical thinking are according to Ennis (2002), which measures six abilities: expressing opinions, making conclusions, outlining reasons, analyzing the reasons put forward, determining actions/formulating alternative solutions, and asking and answering challenging questions.

\section{FINDINGS AND DISCUSSION}

The study results using an independent $t$-test showed a difference between $\mathrm{t}$ count and $\mathrm{t}$ table, which was $6.246>2$,000. These results obtained differences between students who were treated using authentic learning with students who were not treated with authentic learning. The average value of critical thinking skills obtained by the experimental group was 80.73, while that obtained by the control group was 70.37. This shows the effectiveness of authentic learning on the skills of students' critical thinking. Then the research results obtained categories that vary in the tested aspects.

Figure 1 below shows the distribution of critical thinking skills in the experimental class and control class. There is a considerable difference in making conclusions with a difference of $23 \%$, then analyzing reasons by $20 \%$, then in the aspect of formulating alternative solutions by $26 \%$. As for the aspects of expressing opinions and outlining reasons, there are no significant differences.

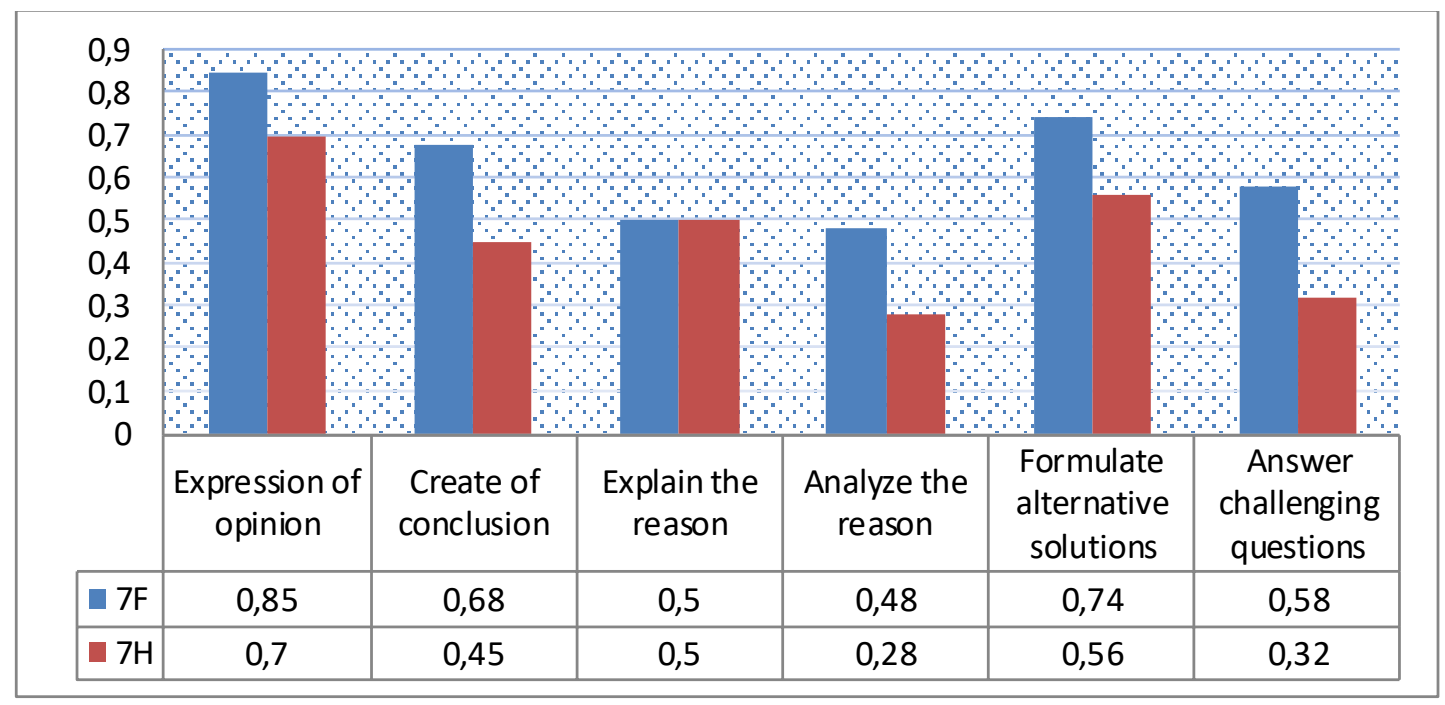

Figure 1. Distribution graph of students' critical thinking skills 
The average ability of students' critical thinking of experimental class is in the high category, marked by having an increased interest in solving critical thinking problems. Students with high critical thinking ability can develop their thinking processes because they are at a superior level of thinking (Nugraha et al., 2017). The indicator of providing alternative solutions to the experimental class is in the high category of $74 \%$. This means that students can think about and discuss alternative solutions in problem-solving with a group of friends and can focus their minds on certain problems or issues. The students learn to critically think through trained habits of problem formulation and question answers that need an explanation to be able to explore all areas of knowledge (Daniati et al., n.d.). One example of a question from this indicator is to ask students to formulate problems from the discourse that has been given. The skill of problem formulation is essential so that the students understand what steps will be employed in problem-solving.

The indicators concluded that students make conclusions, identifying the elements needed to conclude data, reports, or opinions. Deductive reasoning refers to conclusions from specific to general, whereas inductive reasoning refers to conclusions from general to specific (Rahmawati et al., 2016). Conclusion indicators are measured from the ability of students to conclude thoroughly and by existing concepts (Hanim, 2020). The percentage of students' overall answers obtained on this indicator is $68 \%$ and belongs to the medium category. Based on the research results, authentic learning can build students' critical thinking skills. The abilities formed include students' ability to explore their abilities in class, be active in discussions, and use the experiences and information they get based on existing realities, both abstract and artificial situations. This is in line with Donovan et al. 1999; Sulistiani (2018), authentic learning is a pedagogical approach that permits the students to discover, consult, and meaningfully form a new concept in a problem relationship involving the real world with a relevant project. "authentic" means an expert, true, and real (Webster's Complete Revised Dictionary, 1998). In addition, the study conducted by Meitiyani et al. (2019) also showed that authentic learning had a considerable influence on students' creative thinking abilities.

Students' awareness of efforts to increase knowledge, confidence, and curiosity in authentic learning builds students' critical thinking skills. Students no longer learn facts from rote but based on reality, experiences, and information they get outside the classroom. Hence, it can be concluded by analyzing the knowledge obtained into new knowledge based on relevant research that supports it. Critical thinking is a habit to be able to open oneself to analyze, synthesize, and evaluate information to solve a problem (Dixon in Widdy (2018)). In addition, students' critical thinking skills have increased after being given challenging problems and adapted to real situations and close to students' daily lives (Belecina, 2018).

The problem concerned with students' critical thinking skills in this research was that a large number of students had difficulties describing the aspects of reasoning and analysing reasons. As stated by Facione in Kholid (2018), the core of the critical thinking stages, one of which is the need for an explanation, where the stages are to state and justify reasoning with a reason based on evidence, conceptual, methodological, critical, and contextual considerations based on one's results, and the ability of students to convey reasons from the results of one's argumentation in the form of a plausible argument. From the problem, it is suggested that there should be more extensive research so that students' difficulties in describing and analysing a reason can be resolved. 


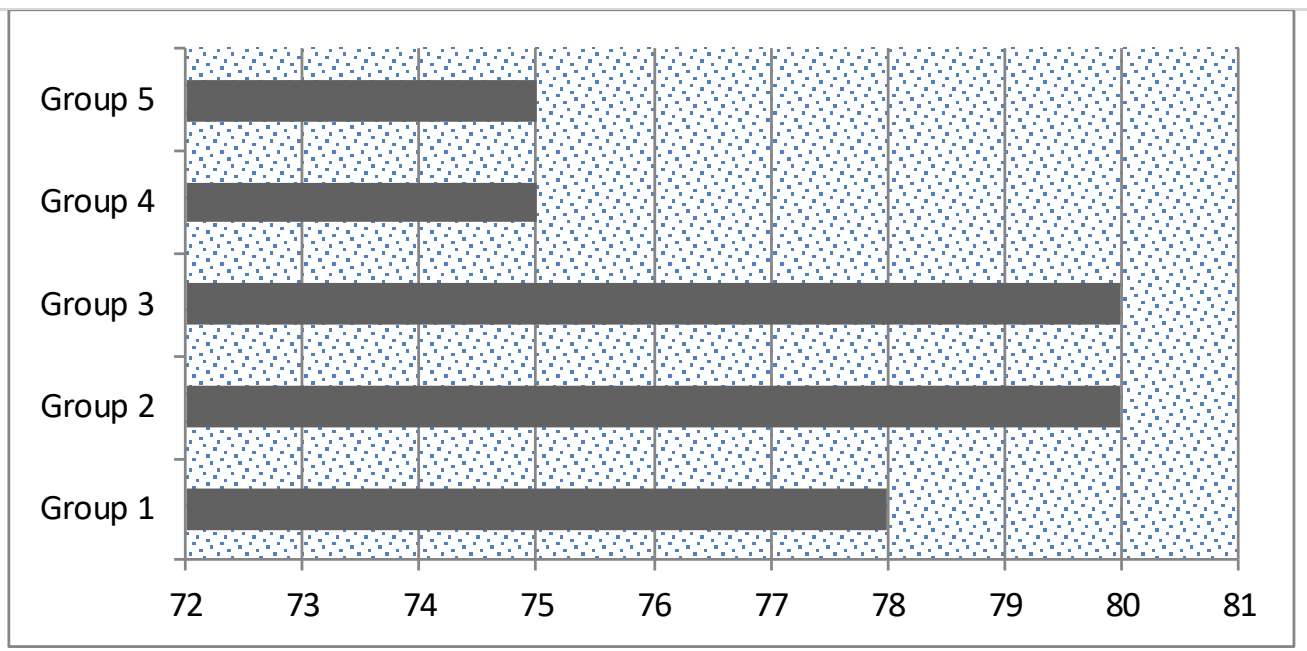

Figure 2. Eco-brick Product Assessment Results

The results of the product assessment show that students have been able to design eco-bricks that are solutions to environmental problems. Authentic activities carried out are:

1. In planning activities

After explaining the material about environmental problems, students and their group of friends prepare the tools and materials that will be used to make eco-bricks.

2. In the activity of making eco-bricks

a. Students and group mates have been very good at preparing materials in the form of plastic that has been cleaned and dried.

b. In the manufacturing process, only group 2 and group 3 can complete the product because of good cooperation with the group and have prepared in advance from home.

c. Almost all groups can show accuracy in making products and can prioritize cleanliness.

3. At the end of the activity

a. Only group 2 and group 3 can finish the eco-brick product well.

b. In the innovation category, students are quite good at developing their eco-brick products.

The novelty of this study is the use of the Eco brick social campaign in authentic learning which can build and improve critical thinking ability. It is expected that other social campaigns can be developed for different content, especially for authentic learning.

\section{CONCLUSION}

Students' critical thinking skills can be developed through authentic learning opportunities such as designing eco-brick social initiatives. For example, the difference in average critical thinking skills between the experimental class $(7 \mathrm{~F})$ and the control class $(7 \mathrm{H})$ using authentic learning, which shows an average of 80.7 per cent, and the control class $(7 \mathrm{H})$, which shows an average of 70.3 per cent, demonstrates this. On the other hand, most students find it difficult to think critically about describing and analyzing their arguments. Student designers are doing a commendable job when it comes to creating eco-brick items. This demonstrates that students recognize eco-bricks as a viable alternative solution to the problem of excessive plastic waste generation. Following further investigation, it is anticipated that more social campaigns for diverse material, particularly authentic learning, would be developed. 


\section{REFERENCES}

Belecina, Rene R. \& Jose M. Ocampo, Jr. (2018). “Effecting Change on Students' Critical Thinking in Problem Solving" in EDUCARE: International Journal for Educational Studies, Volume 10(2), February, pp.109-118.

Bustami, Y., Syafruddin, D., \& Afriani, R. (2018). The implementation of contextual learning to enhance biology students' critical thinking skills. Jurnal Pendidikan IPA Indonesia, 7(4), 451-457. https://doi.org/10.15294/jpii.v7i4.11721

Daniati, N., Handayani, D., Yogica, R., \& Alberida, H. (n.d.). Analisis Tingkat Kemampuan Berpikir Kritis Peserta Didik Kelas VII SMP Negeri 2 Padang tentang Materi Pencemaran Lingkungan Analysis Of Critical Thinking Skill Level Of Students Smp Negeri 2 Padang about Environmental Pollution. Atrium Pendidikan Biologi, 1-10.

Ennis, Robert H. (2002). Goals for a critical thinking curriculum and its assessment. In Arthur L. Costa (Ed.), Developing minds (3rd Edition). Alexandria, VA: ASCD. Pp. 44-46

Ennis, Robert. H. (2011). The Nature of Critical Thinking: An Outline of Critical Thinking Dispositions and Abilities. University of Illinois Last

Fraenkel, JR., \& Wallen, NE.,. (2009). How to Design and Evaluate Research in Education (Seventh ed.). NewYork : McGraw-Hill.

Hanim, N. (2020). Analisis Kemampuan Berpikir Kritis Peserta Didik MTsN Sabang Melalui Implementasi Model Pembelajaran Discovery Learning. Lantanida Journal, 7(2), 171. https://doi.org/10.22373/lj.v7i2.5226

https://www.ecobricks.org/what/

Herbert, Nold. (2017). Using Critical Thinking Teaching Methods to Increase Student Success: An Action Research Project. International Journal of Teaching and Learning in Higher Education. Volume 29, Number 1, 17-32

King, B., Newmann, F.M., \& Carmichael, D.L. (2009). Authentic intellectual work: Common standards for teachingsocial studies. Soc. Educ., 73, 43-59

Kholid, I. (2018). Analisis Kemampuan Berpikir Kritis Dalam Pemecahan Masalah Matematika. Tesis. Universitas Islam Negeri Maulana Malik Ibrahim. Malang.

Kemendibud. (2017). Panduan Implementasi Kecakapan Abad 21 Kurikulum 2013. Jakarta : Ditjen Pendidikan Dasar dan Menengah.

Lombardi, Marilyn. (2007). Authentic Learning for the $21^{\text {st }}$ Century: An Overview.

Loseby, David. (2019). Critical Thinking Skills

Lukitasari, M., Purnamasari, I., Utami, S., \& Sukri, A. (2019). Blended-Problem-Based Learning: How its impact on students' critical thinking skills? JPBI (Jurnal Pendidikan Biologi Indonesia), 5(3), 425-434. https://doi.org/10.22219/jpbi.v5i3.10048

Noviyanti, E., Rusdi, R., \& Ristanto, R. H. (2019). Guided Discovery Learning Based on Internet and Self Concept: Enhancing Student's Critical Thinking in Biology. Indonesian Journal of Biology Education, 2(1), 7-14. https://doi.org/10.31002/ijobe.v2i1.1196

Maina, F.W. (2004).Authentic learning: Perspectives from contemporary educators. J. Authent. Learn. 2004, 1, 1-8

Maier, R., Angway, I., \& Himawati, A. (2017). Plastik, Lingkungan dan Ecobricks

Meitiyani, M., Nadhiro, N., \& Syaban, A. (2019). Membangun Kemampuan Berpikir Kreatif untuk Mengatasi Masalah Lingkungan dengan Menggunakan Pembelajaran Otentik. EDUSAINS, 11(2), 297-302. doi:https://doi.org/10.15408/es.v11i2.13066

Nazim Ali, Russell C,. Margaux H,. (2019). Critical thinking in PBL: Development of a bespoke tool for critical thinking. 5th International Conference on Higher Education Advances (HEAd'19) Universitat Polit `ecnica de Val `encia.

Nugraha, A. J., Suyitno, H., \& Susilaningsih, E. (2017). The Effect of Problem Based Learning model on students' Critical Thinking Skills, Science Process Skills, and Motivation in 
elementary school. Journal of Primary Education, 6(1), 35-43.

Nuryanti, Lilis,.Diantoro, M,. \& Zubaidah, S. (2018). Analisis Kemampuan Berpikir Kritis Siswa SMP. Jurnal Pendidikan. Vol. 3, No. 2. Hal 155-158

Rahmawati, I., Hidayat, A., \& Rahayu, S. (2016). Analisis Keterampilan Berpikir Kritis Siswa SMP Pada Materi Gaya dan Penerapannya. Pros. Semnas Pend. IPA Pascasarjana UM, Vol. 1, pp. 1112-1119.

Rachmadtullah, R. (2015). Kemampuan Berpikir Kritis Dan Konsep Diri Dengan Hasil Belajar Pendidikan Kewarganegaraan Siswa Kelas V Sekolah Dasar. Jurnal Pendidikan Dasar, 6(2), 287.https://doi.org/10.21009/jpd.062.10

Sarimanah, T. (2017). Meningkatkan Kemampuan Berpikir Kritis Matematik Siswa Smp Melalui Pendekatan Problem Posing. Prisma, 6(2). https://doi.org/10.35194/jp.v6i2.123

Sulistiani Dwi (2018). Penerapan Metode Outentic Learning Dapat meningkatkan pembelajaran Ilmu Pengetahuan Alam. Jurnal Penelitian Guru FKIP Universitas Subang. Vol 1(2). 23-32

Widdy. S.N. Peningkatan Kemampuan Berpikir Kritis dalam Penguasaan Konsep IPA Siswa SD dengan Menggunakan Model Problem Based Learning. Jurnal Pendidikan Dasar. Vol 10(2). Hal 115-127. 